\title{
Giulio Grablovitz (1846-1928) and his scientific activity based on personal and institutional correspondence
}

\author{
Graziano Ferrari \\ Istituto Nazionale di Geofisica e Vulcanologia, Bologna, Italy
}

\begin{abstract}
Giulio Grablovitz was one of the leading figures in Italian and international seismology from the second half of the 1880s up to the 1920s. The documentary assets of his long, multifaceted and intense scientific experience consist of several thousand items, amongst which seismic and instrumental recordings, scientific correspondence, publications, bulletins, various manuscripts and photographic materials. What remains from the observatory's original wealth of instrumental equipment is: the seismic tank, some masses and the precision pendulum time-keeping clock. Some partial operations of cataloguing, reproduction and study have so far allowed us to appreciate the great value and scientific and historical utility of the various published and unpublished components, which are individually of great value, but taken as a whole represent a unique heritage.

The cross-matching of this documentation with other Italian epistolary archives allows us to sketch a preliminary profile of Grablovitz, his scientific and human character, together with his fundamental contribution to the birth and development of the Italian geodynamic service and the development of the experimental seismology of his day.
\end{abstract}

Key words scientific letters - earth sciences Grablovitz

\section{Introduction}

Giulio Grablovitz was one of the leading figures in Italian and international seismology from the second half of the 1880s up to the 1920s. The documentary assets of his long, multifaceted and intense scientific experience consist of several thousand items, amongst which seismic, meteorological and oceano-

Mailing address: Dr. Graziano Ferrari, Istituto Nazionale di Geofisica e Vulcanologia, Sezione di Bologna, Via Donato Creti 12, 40128 Bologna, Italy; e-mail: ferrari@bo.ingv.it graphic recordings, publications, seismic bulletins, scientific journals, various manuscripts, photographs and photographic plates. The following items survive from the original instrumental equipment of the observatory: the seismic tank, some masses and the precision pendulum time-keeping clock. For a number of years the historical materials had been stored in the rooms of the observatory and the damp conditions and partial decay of the rooms has not been of help in preserving the historical materials, seeing that part of the documentation has been damaged. Some partial operations of cataloguing, reproduction and study have so far allowed us to appreciate the great scientific and historical value and utility of the various published and unpublished components, which are individually of great value, but when taken as a whole represent a unique heritage. 
The long period of abandonment of the documentation and the subsequent interventions have substantially mixed up the historical materials and only a thorough project of reordering, cataloguing and restoration can make this wealth of materials completely usable once more. This contribution uses only part of the correspondence to sketch an initial biographic profile of Grablovitz and his activity at the Ischia observatories which he himself had designed and set up. Along this path we shall bring to life some of Grablovitz's manuscripts and some of the epistolary and administrative documentation of the $D i$ rezione Generale dell'Agricoltura (General Direction of Agriculture), preserved at the Central State Archives (CSA), which the Ufficio Centrale di Meteorologia e Geodinamica (UCMG Central Office of Meteorology and Geodynamics) depended on.

\section{Giulio Grablovitz and the Observatories of the Island of Ischia}

Giulio Grablovitz was born in Trieste on 9th December 1846, during the Austrian occupation. He was very keen on earth physics and cosmic physics, and soon started dealing with astronomy and oceanography. He obtained Italian citizenship in $1885\left(^{1}\right)$.

Here are some biographical notes that we have gleaned from his short unpublished diary.

His astronomical interests, which were so useful to him also in his seismological practice, as we shall see later, began early in his childhood, as he wrote in his diary: 29th July 1851 Partial eclipse of the sun observed from the roof window with smoked glass $\left({ }^{2}\right)$.

He came from a family of traders, and started his studies in November 1857 at the Academy of Commerce and Nautical Studies (AG, Diario). In $1861\left(^{3}\right)$ with all of his family he moved to Milan. Shortly afterwards he started to help with his family's business activities (AG, Diario). In 1869 he moved back to Trieste. In 1874 he published his first astronomical work on the calculation of the celestial phenomena recorded in Trieste and in Italy predicting a partial eclipse, a covering and a passage of Venus over the sun that indeed occurred on 10th

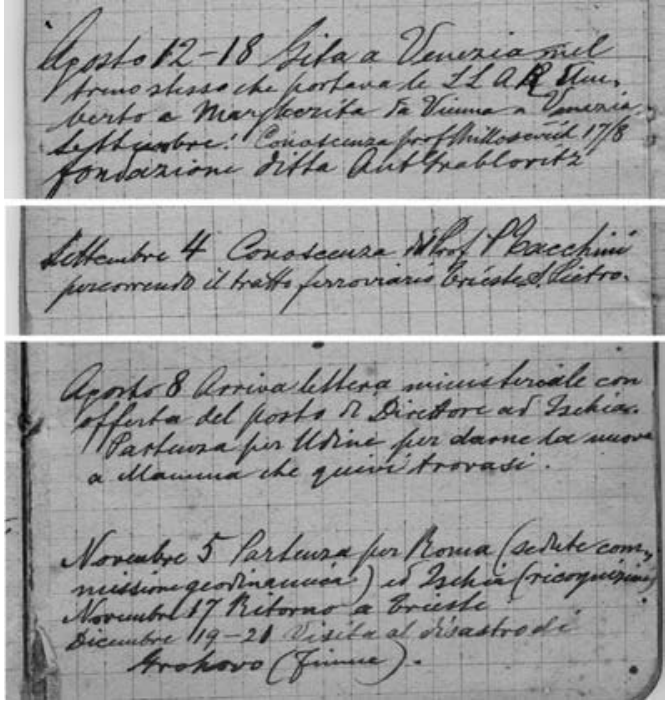

Fig. 1. Parts of the pages of the Grablovitz Diary in which there is mention of a) 17 August 1876 the meeting with Elia Millosevich, and b) September 4, 1880 with Pietro Tacchini, deputy-director of the UCM and director of the UCM, respectively. In c) the letter with the offer of the position of director of the Ischia Observatory arrived on August 8, 1885.

and 14th October and on 9th December of the same year respectively (AG, Diario). The following year, when there was an extraordinarily high tide at Trieste which Grablovitz called «(...) the inspiration for new scientific concepts» (AG, Diario), he published tables of tides, suggesting the use of new types of oceanographies.

In 1876 he published the New Seismic Theory of Tides and in August of the same year, on a trip to Venice, Grablovitz met Elia Millosevich, deputy director of the UCM (fig. 1).

These were crucial years when the scientific events in Grablovitz's life were interwoven with those of another great protagonist of seismology of those days: Michele Stefano De Rossi. De Rossi was keen on geodynamics starting from 1868 , but only embarked on its study in the early 1870 s. He wanted to pursue his objective of organising the observations of geodynamic phenomena, and personally committed himself, be- 


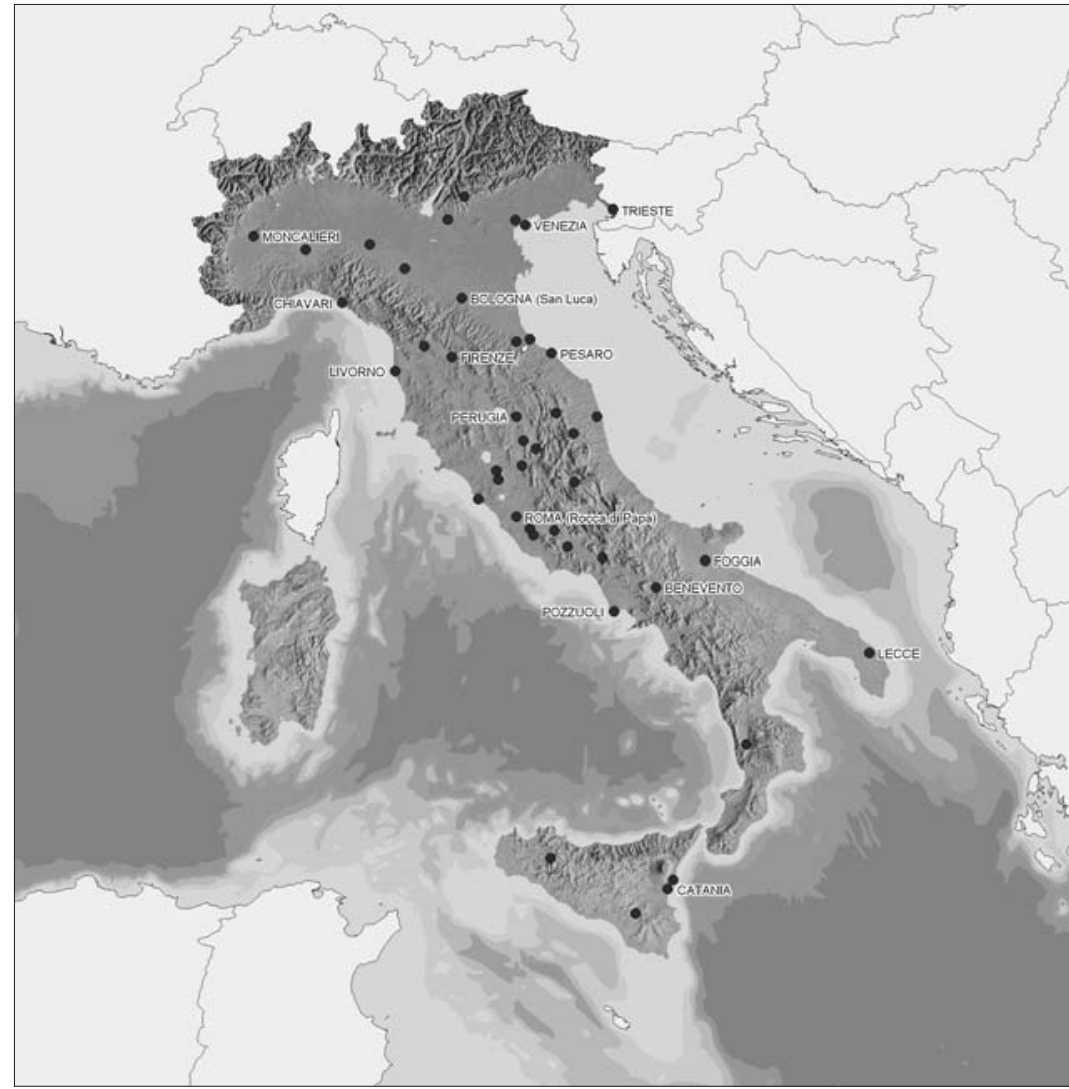

Fig. 2. Sites of the tromometric observations activated between 1870 and 1888 . From 1873 the observatories gradually engaged in regular correspondence with De Rossi who collected the data and published them in his Bullettino del Vulcanismo Italiano.

ginning in 1873, to organising a network of correspondents. A year later he launched the publication of the Bullettino del Vulcanismo Italiano $(B V I)$, which was supposed to represent a centre for collecting data and discussing results, as well as the main promotional vehicle for the fledgling organisation (fig. 2).

The Bulletin was the first real review wholly dedicated to the earth sciences, drafted almost exclusively by De Rossi himself. The success of the great adventure he had devoted himself to four years before was already apparent in 1877: the correspondents of the Bulletin had risen to 105 - Giulio Grablovitz, Antonio Stop- pani and Torquato Taramelli among the new members - and De Rossi was able to announce that he had «managed to found a near-Society or a new School for the studies of endogenous phenomena in Italy».

At the end of 1877, Grablovitz published a work on the effects of lunisolar attraction (Rapporti fra i moti microsismici e l'azione lunisolare delle maree).

In 1880 he met Pietro Tacchini, the Director of the Central Meteorological Office (UCM) (AG, Diario), by chance on a train journey (fig. 1). After the meeting with Millosevich in 1876, this meeting was a turning point in the life of 


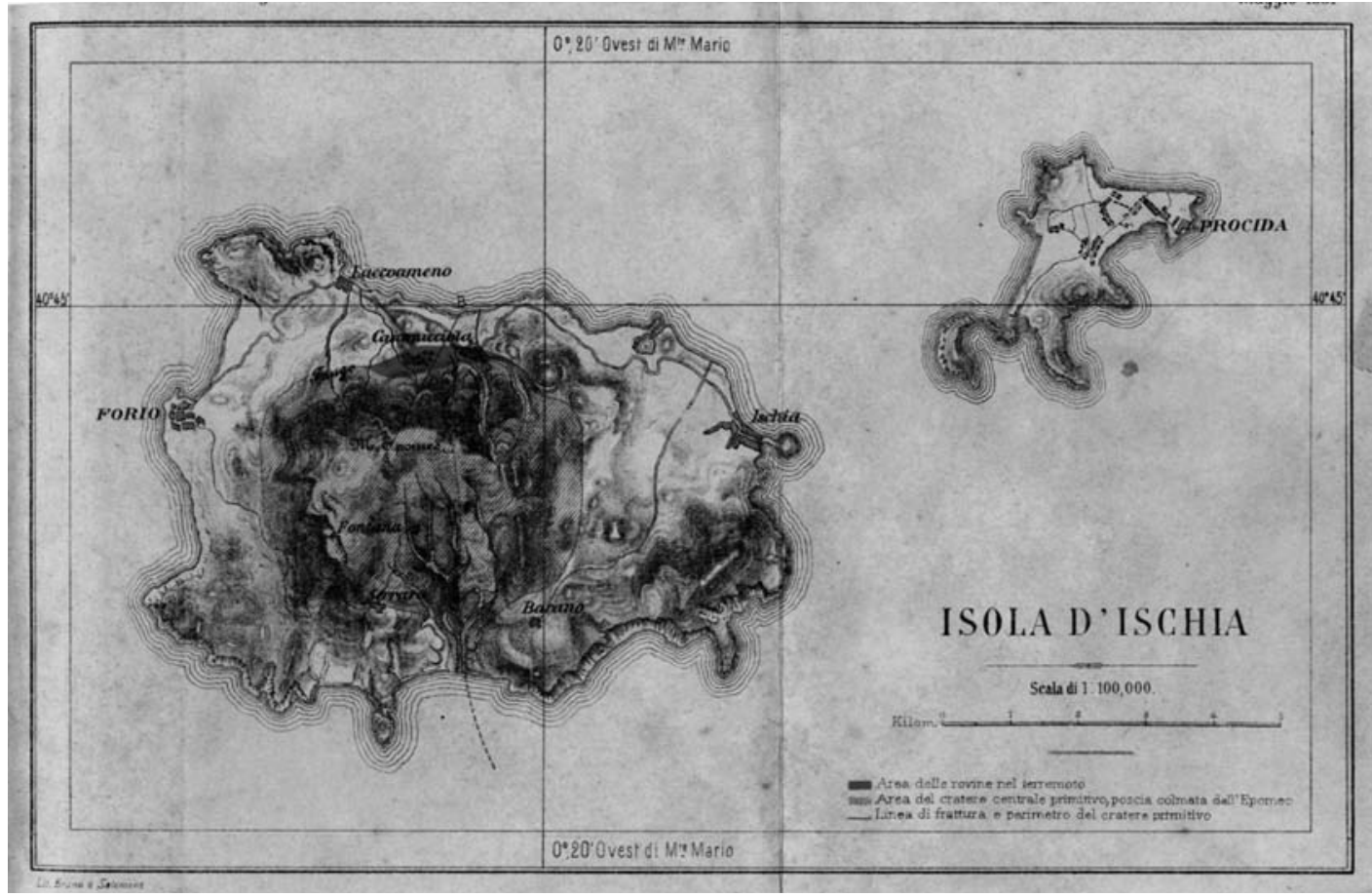

Fig. 3. Thematic map of the seismic effects of the earthquake on 4th March 1881 in the island of Ischia, drawn from the study of De Rossi (De Rossi 1879-1881). The full red area identifies the destructive earthquake effects; the area dotted in red outlines the primitive crater; the red line indicates the fracture line and perimeter of the primitive crater.

the Trieste scholar as well as for the fledgling Italian geodynamic service.

As early as 1881 the engineer Felice Giordano, Chief Inspector of the Mines, recalled people's attention to De Rossi's studies on «Vulcanismo italiano» (letter from Giordano to Miraglia), with the only outcome, however, of delaying a possible Government commitment to De Rossi's field of study. It took two earthquakes, on 4th March 1881 (fig. 3) and 28th July 1883 (fig. 4), both on the island of Ischia, to convince the Government to support De Rossi's research first of all, with the setting up of the Observatory and the Geodynamic Central Archive where De Rossi completely transferred his activities and of which he was appointed director, subsequently to launch a full-blown programme of observation of geodynamic phenomena in Italy.

Encouraged by Millosevich, with a letter on 3rd November 1882, Grablovitz put himself forward to Tacchini for a future collaboration within the scope of geodynamic observatories $\left({ }^{4}\right)$.

In March 1883 De Rossi, with the establishment of the Geodynamic Observatory and Archive at the Royal Geological Committee, wanted to start up «an Endogenous Meteorology service» in Italy, guaranteeing Italy the leadership in this new branch of earth physics, «born and bred in the peninsula which was interested in it»: an authoritative centre situated within a governmental scientific body, albeit in a provisional form, which assured pledges of collaboration and cooperation from all over Italy and even from abroad.

Confirmation came from abroad concerning the international success achieved by the Italian geodynamic service. In particular, the French Ministry of Public Works sent an Inspector of 
Mines, accompanied by another two engineers to study the state of the art. This technical-scientific delegation was particularly appreciative of the Italian experience and, in particular, of De Rossi's competencies.

The new seismic disaster at Casamicciola on 28th July 1883 drove the Government to intervene in an even more incisive manner. The Royal Geodynamic Commission was set up by a decree issued on 20th December 1883; it was chaired by Giovanni Schiaparelli and was composed of Pietro Blaserna, Francesco Denza, De Rossi, Galileo Ferraris, Giordano, Luigi Palmieri, Francesco Rossetti, Orazio Silvestri and Tacchini $\left(^{5}\right)$. The commission, which in the meantime changed its president twice - Schiaparelli who resigned and his successor Quintino Sella who died (14th March 1884) - only met for the first time at the end of May 1884 under the chairmanship of Blaserna. One of its preliminary aims was to set up three large Observatories «at the centre of the main volcanic regions of the country»: that is to say, Rocca di Papa, the central point of the Vulcano Laziale, Casamicciola, site of the recent disastrous seismic phenomena, and Catania. The establishment of observatories in other points of interest was put off to a later date. Numerous secondary observatories were supposed to depend on these main observatories.

Grablovitz accepted the position given to him by Blaserna on 15th September 1884, according to his diary (AG, Diario). However, according to Tacchini's correspondence from the State Central Archives, he was to deal with the installation of the geodynamic observatory in Casamicciola $\left({ }^{6}\right)$. From 11th to 15th December of the same year, Grablovitz accompanied by de Rossi, Tacchini, L. Baldacci, De Ferrari, Carrara and Amato, surveyed the island of Ischia to identify the location best suited to setting up the observatory and to come to an agreement with the municipal authorities $\left(^{7}\right)$.

On 18th December 1884 Blaserna presented the report given to him on the same day by Grablovitz to the Ministry of Agriculture $\left({ }^{8}\right)$, concerning the inspection performed on the island of Ischia. In the report the hill called Grande Sentinella was suggested as being the right place to build the observatory. It was situated in the central part of the zone that had suf-

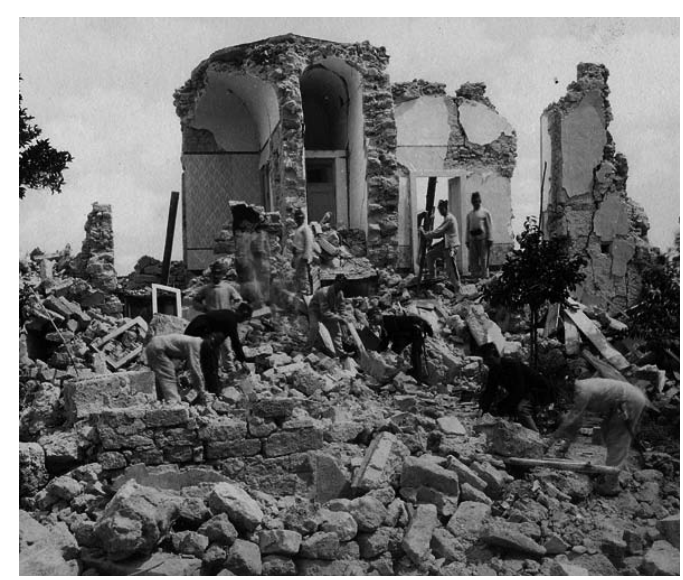

Fig. 4. Rare photograph of the effects of the earthquake on 28th July 1883 in Casamicciola (Archives of SGA Storia Geofisica Ambiente, Bologna).

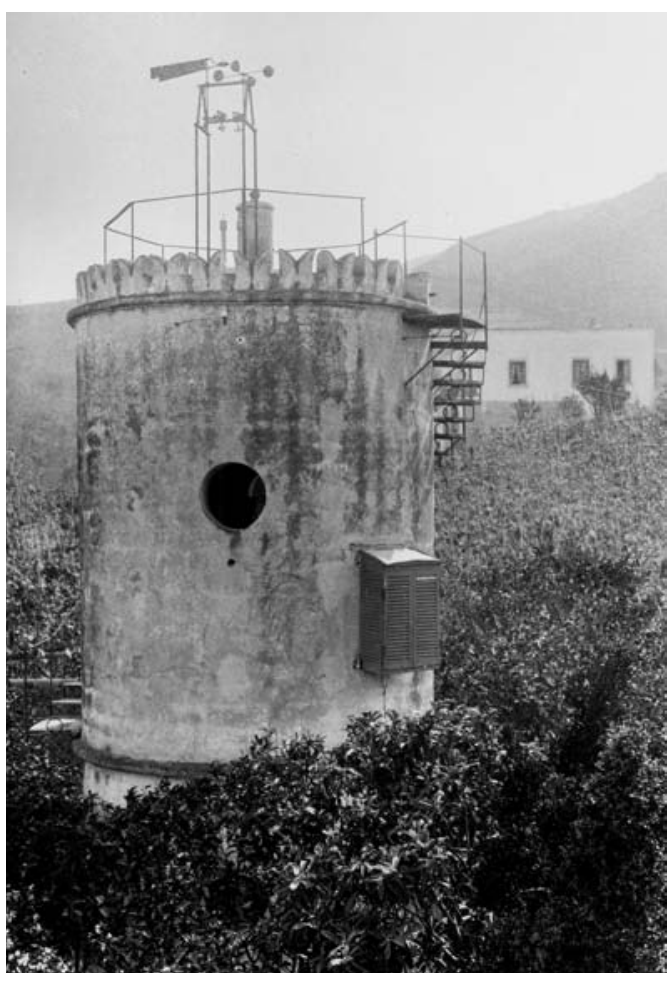

Fig. 5. Dovecot annexed to the Casina Reale set up as a weather tower, in a late 19th century photograph (Grablovitz Archive). 
fered the most damage due to the earthquake on 28 th July 1883 . It was characterised by its solidity and field of vision: from that point the surrounding mountains, the islands and Vesuvius could be seen. Among the various ideas expressed in the work, Grablovitz added the hypothesis of setting up other subsidiary stations, amongst which one to be situated in proximity to the port of Ischia, at «Casina Reale», licensed by the Ministry of War $\left({ }^{9}\right)$. That observatory was certainly ready in a short time, and would have allowed for preliminary geodynamic research to be carried out, together with very useful mareographic and meteorological studies $\left({ }^{10}\right)$ (fig. 5), even before the Observatory of the Grande Sentinella had been completed.

On 23rd January 1885, the Ministry of Public Works commissioned Gambara, who was the Ingegnere Reggente l'Ufficio Speciale del Genio Civile, with the job of drafting the project for the Geodynamic Observatory of Casamicciola and seeing to the relevant preliminary operations of expropriation, vacating of disused farm buildings and the removal of shacks $\left({ }^{11}\right)$. In November of that year, in spite of the repeated requests, the project for the building had not yet been completed, whereas the work for the organisation of the subsidiary observatory at «Casina Reale» appeared to be well underway $\left({ }^{12}\right)$.

Following the Royal Decree passed on 24th July 1885, King Umberto I appointed G. Cantoni, T. Taramelli and G. Grablovitz as members of the Royal Geodynamic Commission and confirmed Blaserna as President $\left({ }^{13}\right)$.

On 8th August 1885 Grablovitz received a letter in Trieste from the Ministry with the offer of a position as Director on the island of Ischia (AG, Diario), which he accepted and which was followed by the official communication of the Royal decree of appointment $\left({ }^{14}\right)$.

In a note dated 18th April 1886 Grablovitz urged Miraglia to see to it that the appropriate geological surveys be carried out to test the stability of the ground, promised by Baldacci back in 1884, and required in order to obtain the approval for the project presented to the Ufficio del Genio Civile ${ }^{15}$ ). On 15th June 1886 GG presented the definitive report for the Geodynamic Observatory of Ischia to the Royal Geodynamic Commission which unanimously ac- cepted, making it the opening article of the 4th part of the UCM annals (AG, Diario).

On the occasion of the second meeting of the Geodynamic Commission from 14th to 16 th June 1886 , a proposal was made to the Government to set up a full-blown Central Geodynamic Office. The many relations developing between meteorology, geodynamics and the other branches of earth physics had led the Commission to suggest to the Government that it should also entrust the publication of the geodynamic observations to the Central Office of Meteorology, leaving the directors of the main station with the responsibility to direct the works and transmit the recordings to the Central Office. In this way the UCM took on the character of a central office for the whole of Earth Physics, making the office faster and more united. All of this was handed over to the authority of Tacchini, director of the office, who hoped to have the Italian geodynamic sector gain, in a few years, the development that everyone already acknowledged to Italian meteorology.

The last meeting of the Royal Geodynamic Commission was held in January 1887, on the occasion of which the organisation of the Italian seismic service was established.

On 23rd February 1887 a disastrous earthquake hit western Liguria and the death and destruction it caused represented a further point pressurizing the government to complete the process of installing a permanent, organised, institutional geodynamic service in Italy.

A private diatribe between Grablovitz and De Ferrari, which started in 1886 and went on until 1889 and which cost Grablovitz a prison sentence, later turned into internment in Rome, and De Ferrari's definitive removal from Ischia, slowed down the establishment of the Ischia observatories.

During Grablovitz's period of absence from Ischia, Giovanni Agamennone (September) and later Luchesi (December) $\left({ }^{16}\right)$ (AG, Diario) were appointed as assistants for the continuation of the observations at Casamicciola.

Again in 1887 the Geodynamic Commission was broken up but, as Tacchini explained, the management of the geodynamic service was entrusted to him and his UCM as there 
were insufficient economic resources to create an independent service $\left({ }^{17}\right)$.

The period of the construction and start up of the observatory was a particularly laboured one for Grablovitz. The scientific activities were significantly hampered owing to the poor quality of the building work and the materials used. For Grablovitz there started a period of arguments and general disagreement with the civil engineers of Naples, entrusted with overseeing the work done by the Direzione Generale dell'Agricoltura. The difficulties he came across convinced him to bring forward the instrumental outfitting of the subsidiary Observatory of Porto d'Ischia which, even after the inauguration of the main observatory of $L a$ Grande Sentinella of Casamicciola, remained his favourite workplace.

As soon as he had come back from a forced absence (i.e. prison and internment in Rome), Grablovitz started to process the data that he had collected in the meanwhile at his observatory and he devoted himself to oceanographic studies that would later lead him to the publication of a study on the tides of Ischia (Ricerche sulle maree d'Ischia (AG, Diario)). The Ministry of Agriculture, following the shocks felt and the eruptive phenomena in progress on the Aeolian islands, on the grounds of a proposal of the Consiglio Direttivo di Meteorologia, agreed to involve Prof. Giuseppe Mercalli in the study of the Lipari volcanic eruption $\left({ }^{18}\right)$.

On 1st February 1889, Tacchini, after having commissioned Grablovitz to go to Lipari for study reasons, came to an agreement with the Ministry of Agriculture to see that De Ferrari be removed from Ischia, taking advantage of Grablovitz's absence $\left({ }^{19}\right)$, who nonetheless was not going to be absent from Ischia for very long. His presence was absolutely necessary to implement a series of initiatives already in progress, and above all «finally», after a very difficult period studded with lengthy absences $\left({ }^{20}\right)$.

On his part, Grablovitz accepted the job of going «to the Lipari islands» to study the phenomena in progress in that period, in turn expressing the need to go back to dealing with the construction of the Observatory of Casamicciola as soon as he could, something that had always been hampered by a variety of problems $\left({ }^{21}\right)$. After a one-year ab- sence, for the preceding 3 months he had worked hard to make up for the damage and it would have been a pity if a new suspension had made all his work and effort vain $\left(^{22}\right)$.

On 8th February 1889, Grablovitz and Mercalli left Naples to go to Messina and Lipari following Silvestri's report of an earthquake in the former location and a volcanic eruption in the latter $\left.{ }^{23}\right)$. Although it had been understood that Grablovitz should rightly deal principally with the Ischia project, his successes in the scientific field made him more suited to the study of the volcanic events of the Aeolian islands $\left({ }^{24}\right)$. Nevertheless, in October 1889 Tacchini pointed out in a letter to the Direzione dell'Agricoltura that Grablovitz would only set up the service on the Aeolian islands and that subsequently it would have been given the control of Catania. The scholar's intervention was deemed necessary as the intention was to set up a proper transmission service between Vulcano and Lipari and the automatic equipment that was to be installed had indeed been developed by him $\left({ }^{25}\right)$.

On 16th July 1889 (AG, Diario), Grablovitz went back to Ischia on a definitive basis $\left({ }^{26}\right)$.

Cuts to resources, spiralling costs due to the breaking up of responsibilities and personal squabbles drove the President of the Consiglio Direttivo di Meteorologia e Geodinamica Blaserna to write, on 1st November 1889, an impassioned letter to the Ministry of Agriculture, Industry and Commerce on the history of the Geodynamic Service in Italy, praising the work of Grablovitz in particular $\left({ }^{27}\right)$.

Section I of the Congress of Genoa in 1892, at the special meeting on 19th September, voted in favour of extending the mareographic research, and that the various central administrations should agree on the plan drafted by Grablovitz. On the occasion of this Congress, Grablovitz took his leave from Casamicciola from 6th September until 18th October, going to Rome and Trieste (AG, Diario). From a series of service notes on 23rd June 1892, written before leaving for Genoa, the Geodynamic Observatory of Casamicciola had its stable location at Porto d'Ischia and comprised the following: the Management Office, the meteorological and geodynamic station, the oceanographic station, the geodynamic station at the Grande Sentinella and 


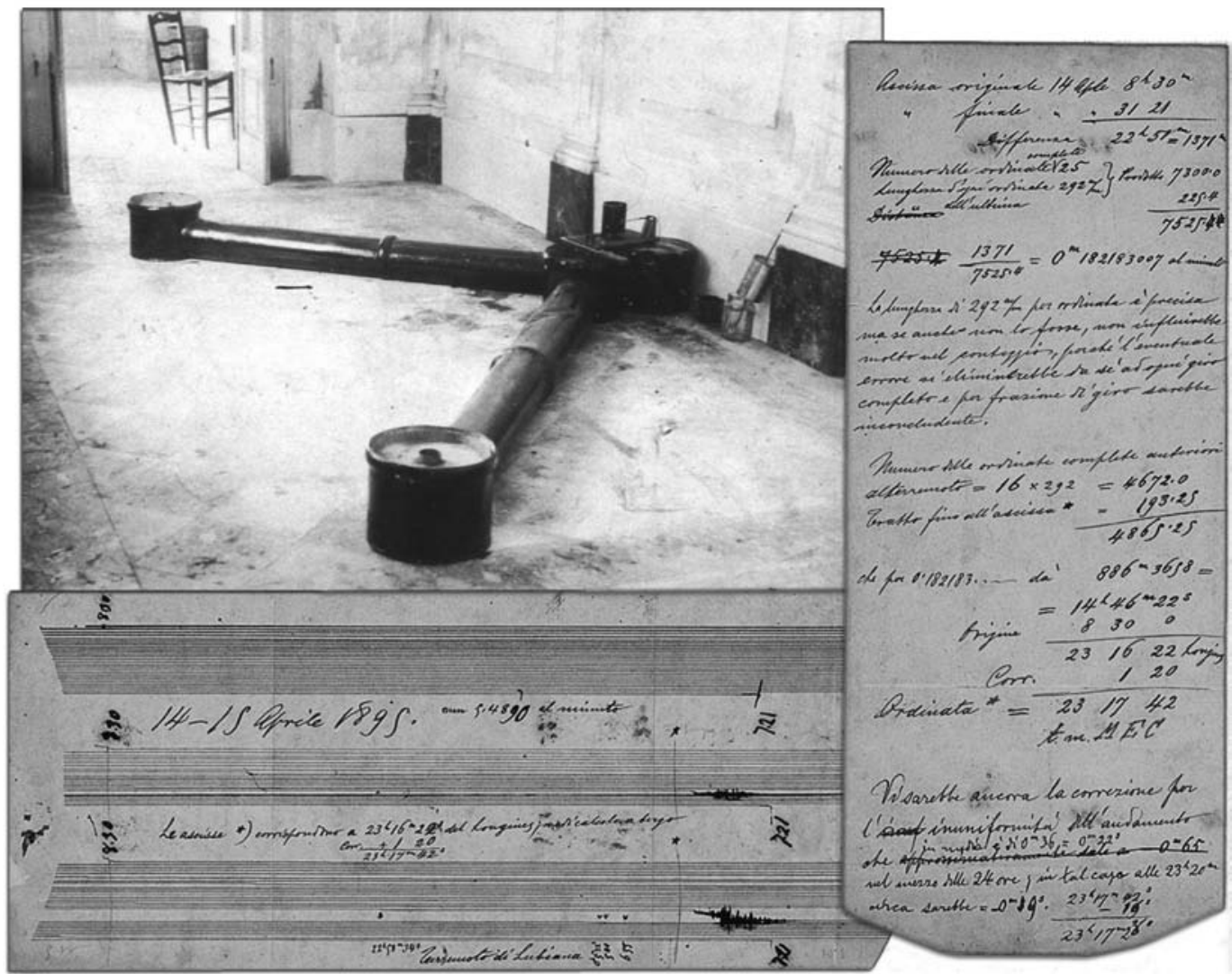

Fig. 6. Seismogram of the Lublin earthquake on 14 April 1895 recorded at the Porto d'Ischia Observatory by the continuous recording geodynamic levels and reverse side of the same seismogram with the calculations and the information systematically summarised by Grablovitz. (Grablovitz Archive).

the hydrothermal points: at the municipal establishment of Ischia, at the Stabilimento balneomilitare d'Ischia and at the Gurgitello $\left({ }^{28}\right)$.

On the occasion of the summoning of the Consiglio Direttivo di Meteorologia e Geodinamica on 26th June 1893 Grablovitz asked Tacchini to see that his programme was implemented, emphasizing its ease and convenience $\left({ }^{29}\right)$.

In 1894 the geodynamic levels he had built were set up in the observatory of Porto d'Ischia, whose first recording was the earthquake of Ljubljana on 14th April 1895 (fig. 6), and in October of that year he obtained the first recording of a teleseism: the earthquake on 27 October
1894 (AG, Diario), $\mathrm{M}=8.0$ San Juan, Argentina with the horizontal electrical alarm pendulums.

At last, the seismic tank Grablovitz had built and perfected at Grande Sentinella $\left({ }^{30}\right)$. recorded its first diagram in 1895 (18th October) even if it did have some problems owing to water leaks (AG, Diario), problems practically solved the following year, by applying bitumen along the walls of the seismic tank (fig. 7). This instrument was one of those that recorded the Indian earthquake on 12th June 1897; after this event Grablovitz added the smoked paper recording system to the ink-based one. In the meantime, on 29th May 1896 (AG, Diario), the 


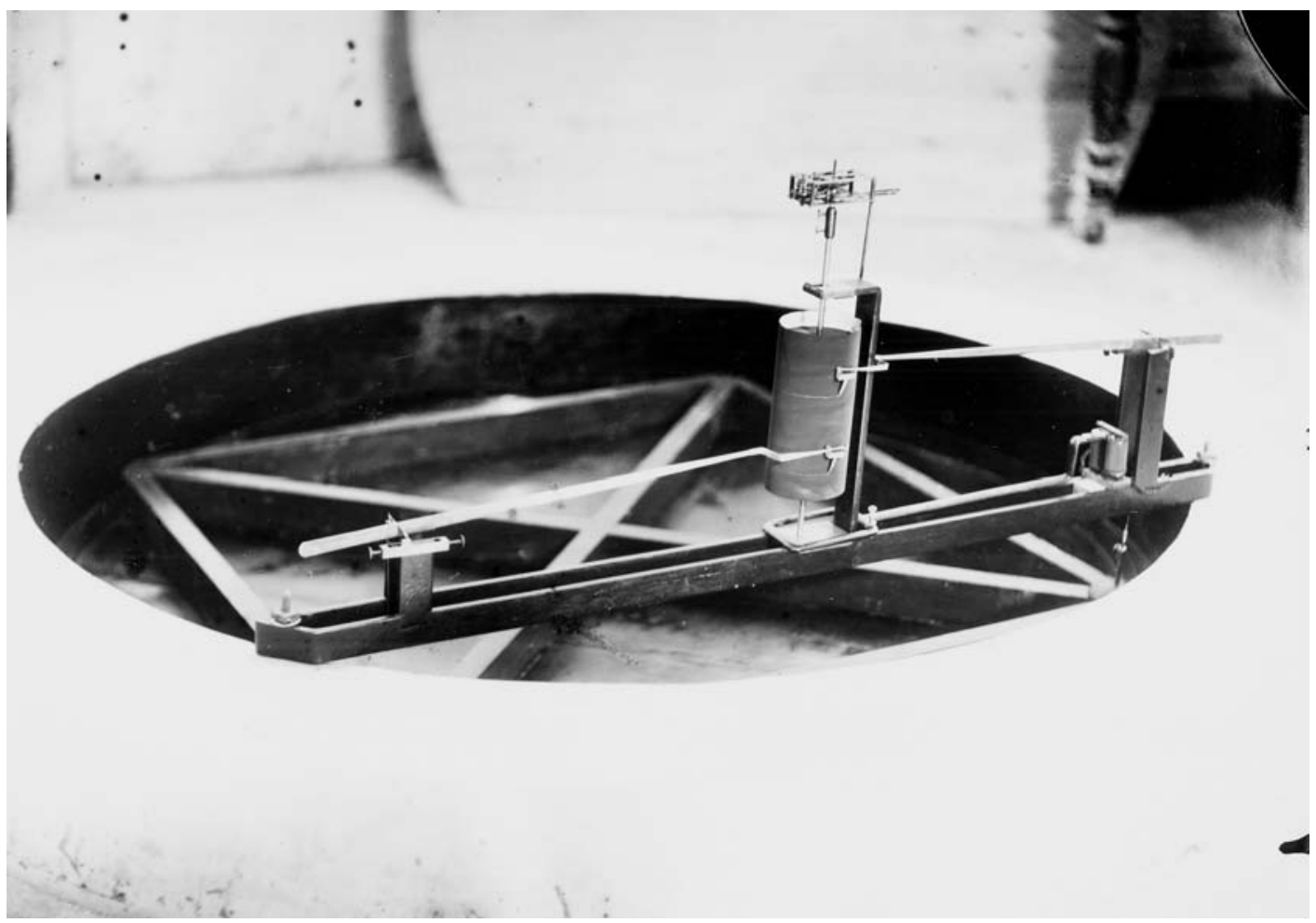

Fig. 7. Grablovitz's seismic tank at the Grande Sentinella Observatory in a rare photograph of the end of 19th century (Archivio Grablovitz). This instrument still exists.

observatory had been equipped at the rooms of Casina Reale $\left({ }^{31}\right)$ with two more horizontal pendulums with masses of $12 \mathrm{~kg}$. In a letter dated 8th June 1896, Grablovitz stressed the great sensitivity and low cost of his invention to Tacchini $\left.{ }^{32}\right)$. These considerations were in time also confirmed abroad $\left({ }^{33}\right)$.

By Grablovitz's own admission in his diary, the construction of these «pendulums with continuous mechanical recording» were the fruit of previous experiences dated in late-March 1895. Thanks to these seismographs he also recorded the Japanese earthquake on 15th June 1896.

The positioning of the new instruments had cast light on the advantages and drawbacks of the different rooms that made up the observatory (fig. 8). Grablovitz, concerned about the possibility aired by Tacchini concerning the clos- ing down of the station at the Port, in a letter dated 1st February 1897, illustrated some defects of the Grande Sentinella observatory, linked to the environmental non-seismic noise enhanced by the increased sensitivity of the instruments designed by Grablovitz and the advantages of the one at Porto d'Ischia $\left({ }^{34}\right)$.

In April 1897, after a series of events involving his assistants in whom he had by then lost all esteem, Grablovitz moved his residence to Grande Sentinella to have the main instruments close to hand and he left one of his assistants at the Port.

In October, owing to a family bereavement, Grablovitz left for Trieste and took advantage of his trip to meet Albin Belar in Ljubljana, with whom he discussed the horizontal pendulums (AG, Diario). 


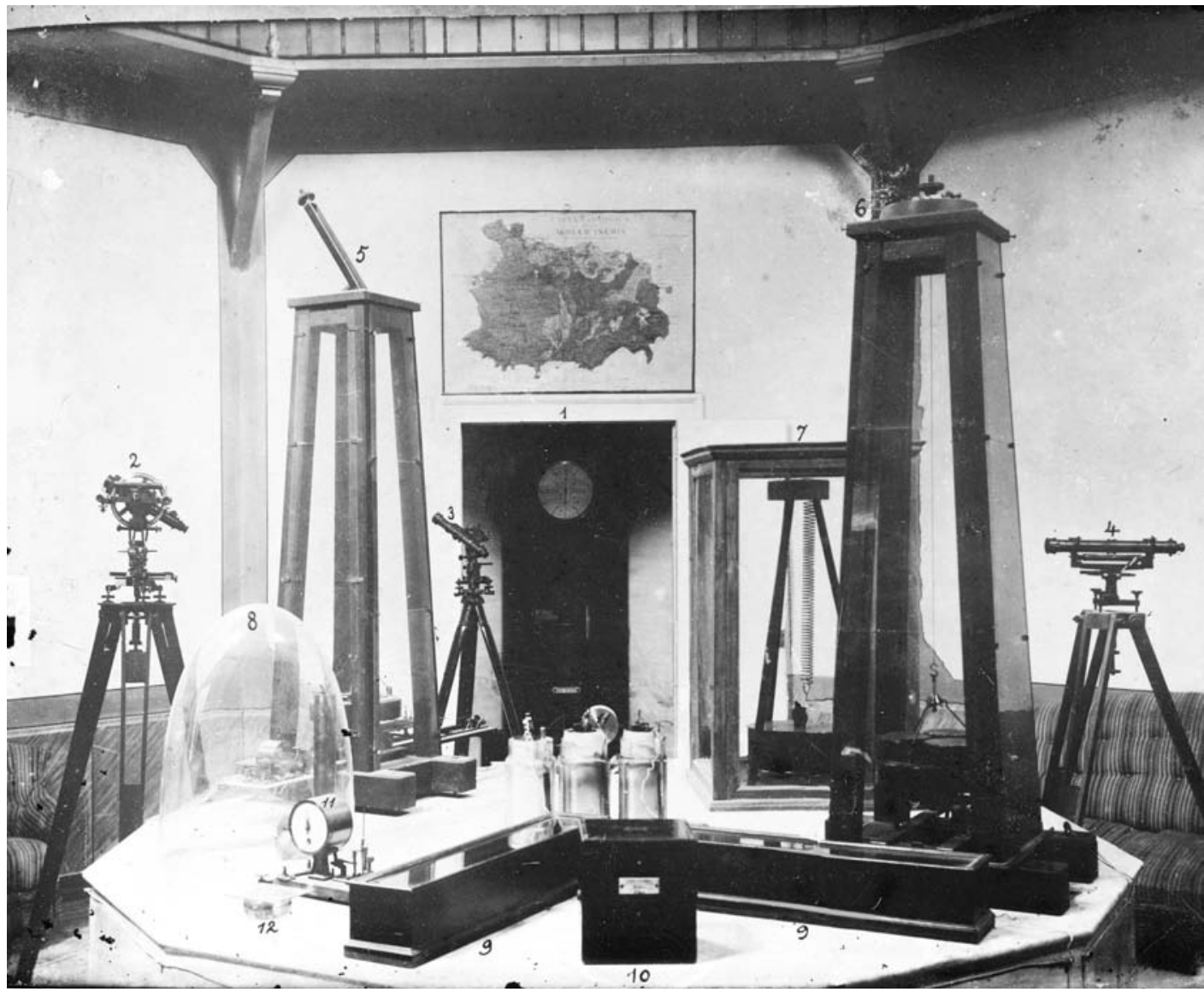

Fig. 8. Seismic instruments hall of the Observatory of the Grande Sentinella of Casamicciola (Island of Ischia) in a rare photograph between the end of the 19th and the start of the 20th century (Grablovitz Archive). In the foreground we can see the small water geodynamic levels of Grablovitz (9), a marine chronometer (10), two Brassart seismometrographs with stationary mass on smoked paper (5) and on a smoked glass pane (6), some topographic instruments (2, 3 and 4$)$ and, in the background, a precision pendulum clock (1). The instrument set is completed by two Brassart rod seismoscopes (11), in the foreground and in the background respectively, in front of a precision clock. Behind the glass bell of the Brassart rod seismoscope we can catch a glimpse of a pair of Grablovitz electric alarm horizontal pendulums. In the same room, not visible, there was also a meridian, with which Grablovitz adjusted the clocks.

In 1906 the instruments designed by Grablovitz won a Gold Medal at the Milan Exhibition. His fame was by then acclaimed and his international collaborations already confirmed, for example, by his correspondence with J. Milne or F. Omori and the use of his in- struments in other observatories, such as those in Spain (Batlló, 2009). It is Grablovitz himself who provided the detailed instructions for the reproduction of his instruments elsewhere, as can be seen from the correspondence with the Ebro observatory on the occasion of the record- 
ing of the California earthquake on 18th April 1906 (Batlló, 2009). Another observatory that used his instruments is that of Ljubljana.

Grablovitz also took advantage of his international collaboration to increase the number of oceanographic data at his disposal relating to the Mediterranean as in the case of the Ebro observatory (Tortosa) in Spain (Batlló, 2009).

At the end of the 19th century, the Casamicciola observatory was among the best equipped and most efficient in Europe. Today we still have Grablovitz's extraordinary archive, which comprises thousands of documents, including letters, seismograms, notes, meteorological and oceanographic observations, etc.

Thanks to his instruments, in particular the seismic tank (fig. 8) Grablovitz recorded some of the most powerful earthquakes of the late 19th century, extraordinary recordings still existing with which attempts have been made to determine the moment magnitude (table I) (Ferrari et al., 2005).

On the earthquake of Assam, the first teleseism recorded in Italy so clearly (fig. 9), Grablovitz wrote an article in BSSI and put forward some considerations on the seismograms of the Japan earthquake on 31st August 1896, which will be discussed later.

In the 1896 seismic bulletin (Notizie 1896, pp. 91-95) Grablovitz, describing the seismogram of the Japanese earthquake on 31st August $1896, M=7.3$ (Abe, 1994), recognised three dif- ferent phases: the first one was characterised by «tremors of negligible size and minimal movements, more accentuated in the meridian than in the parallel and with predominant NNE-SSW direction», the period of oscillations are mostly brief: from 2.5 to $4 \mathrm{~s}$; the second phase consisted in «more noticeable short-term impulses and consisting of longer-lasting oscillations» with oscillation periods in the range of 3.2 and 20s; the third phase «consisting exclusively of longterm oscillations» up to $41 \mathrm{~s}$.

About one year later, on 12th June 1897, an earthquake of 8.1 magnitude hit the area of Assam (North-East India) and was recorded by numerous Italian observatories. Richard Dixon Oldham (1858-1936), of the Geological Service of India, in studying the propagation velocities on the Italian seismograms, recognised three phases in them, but independently from Grablovitz and published a weighty article on them in which he analysed a dozen or so earthquakes far from the recording sites. Some of the elements that could be gleaned from one of his publications and a clarification at distance between Oldham and Grablovitz on the paternity of the recognition of the three phases, can help us to understand some aspects of the history of Italian seismology between the late 19th and early 20th centuries.

Moreover, the issues of the recognition of the different phases that make up a seismogram and that of the sensitivity and the definitive power of the seismographs are central to the un-

Table I. Final results concerning the moment magnitude of some earthquakes of the end of 19th century calculated from original seismograms recorded at the Grablovitz's Ischian observatories.

\begin{tabular}{lccccccc}
\hline \hline Date & Region & Uo & fc $(\mathrm{Hz})$ & $\mathrm{Mo} * \mathrm{E}+18$ & $\mathrm{Mw}$ & $\mathrm{R}(\mathrm{km})$ & Stress Drop (MPa) \\
\hline \multirow{2}{*}{ June 12, 1897 } & India & $0.86714 \mathrm{E}-03$ & 0.106 & 251.39 & $7.60(\mathrm{p})$ & 20.94 & 11.9723 \\
& & $0.29240 \mathrm{E}-02$ & 0.061 & 103.09 & $7.34(\mathrm{~s})$ & 21.01 & 4.8619 \\
\multirow{2}{*}{ September 4, 1899 } & Alaska & $0.14123 \mathrm{E}-03$ & 0.199 & 48.37 & $7.12(\mathrm{p})$ & 11.16 & 15.2412 \\
& & $0.88986 \mathrm{E}-03$ & 0.111 & 35.45 & $7.03(\mathrm{~s})$ & 11.60 & 9.9376 \\
\multirow{2}{*}{ September 20, 1899 } & \multirow{2}{*}{ Turkey } & $0.95183 \mathrm{E}-04$ & 0.387 & 2.66 & $6.28(\mathrm{p})$ & 5.74 & 6.1576 \\
& & $0.20772 \mathrm{E}-03$ & 0.216 & 0.61 & $5.86(\mathrm{~s})$ & 5.93 & 1.2828 \\
\hline
\end{tabular}




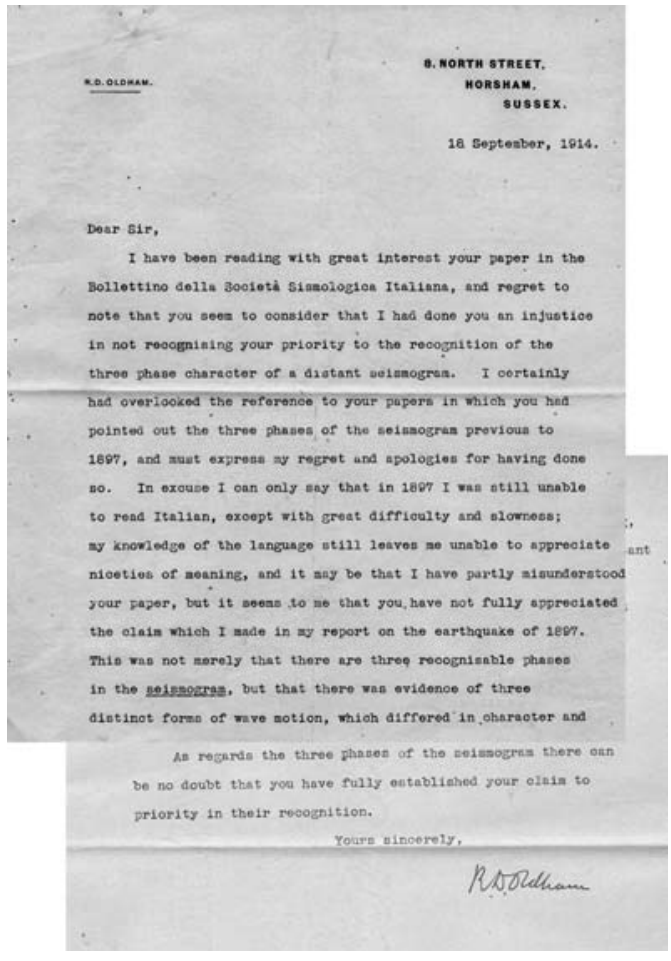

Fig. 9. Letter from R.D. Oldham 1914 to Giulio Grablovitz on 18th September in which the British seismologist recognised without any doubt Grablovitz's priority in the identification of three different phases in seismograms.

derstanding of the internal structure of the earth and the mechanisms generating and propagating the earthquakes, the latter being fundamental aspects in the development of seismology.

In his memorandum Oldham mainly used the data of the Italian observatories and produced the first travel-time curves of seismic waves for distant earthquakes. Table II reports the observatories considered by Oldham among those that recorded the seven earthquakes that he examined. He reports the phases detectable by the seismograms and the distances of the stations from the earthquake epicentres, measured in degrees. As can be seen, out of fifteen observatories, seven are Italian and cover $74 \%$ of the observations made by Oldham and with which he constructed the graph of the propagation velocities of the three wave phases. In his weighty memorandum, the Irish seismologist often referred to Grablovitz, with great respect (he called him «professor», on a par with Milne, while Cancani and Agamennone, just «doctors»), but he hinted to the fact that Grablovitz only recognised two of the three phases in the recordings.

For his work, Oldham is universally attributed as having been the first to recognise these three main phases (Davison, 1927; Milne, 1900; Agnew, 2003).

The story does not finish here and has a follow-up that we have been able to reconstruct only by means of the unpublished documentation of the archive of the Casamicciola observatory. Going back to the aspect of the different phases of the seismograms (Grablovitz, 1913), Grablovitz did not miss the opportunity to challenge Oldham over the record in the recognition of the three phases in the recordings of distant earthquakes, claiming it for himself on the occasion of the Japan earthquake on 31st August 1896.

On 18th September 1914 Oldham wrote to Grablovitz (fig. 9), reconstructing the reasons he had mistakenly failed to recognise Grablovitz's record. He admitted that at the time of his study (Oldham, 1899) he did not read Italian very well with the ensuring consequences. However, Oldham stressed that his work was not limited only to the recognition of the three phases, but that it consisted of three distinct forms of waves that propagated along different paths and at different velocities, consequently arriving at different times $\left({ }^{35}\right)$. Oldham concluded the letter by stating that, in regard to the three phases of the seismogram, there could be no doubt that he (Grablovitz) had established his priority over their recognition.

In the years when the confrontation between Grablovitz and Oldham was unfolding, the Italian seismologist was at the height of his scientific maturity, with a substantial experience behind him as a designer and tester of seismographs, but also with an outstanding experience in interpreting the contents of his seismograms, which the instruments installed at the two observatories of Casamicciola and Porto d'Ischia 
Table II. Phases recognised in the seismograms recorded by the different Observatories taken into consideration by Oldham (1897) for his analyses: $1=$ first phase, $2=$ second phase, $3=$ third phase. Starting from these data he published the graph reported in fig. 10. For some of these sequences, some Observatories recorded more than one shock, indicated in square brackets.

\begin{tabular}{|c|c|c|c|c|c|c|c|c|}
\hline $\begin{array}{c}\text { Observatory } \\
y\end{array}$ & $\begin{array}{c}\text { Country } \\
y\end{array}$ & $\begin{array}{c}22031894 \\
\text { Japan }\end{array}$ & $\begin{array}{r}27101894 \\
\text { Argentina }\end{array}$ & $415061896=$ & $\begin{array}{c}31081896 \\
\text { Japan }\end{array}$ & $\begin{array}{c}12061897 \\
\text { Japan }\end{array}$ & $\begin{array}{c}05081897 \\
\text { Giappone }\end{array}$ & $\begin{array}{c}17091897 \\
\text { Turkestan }\end{array}$ \\
\hline Catania & I & & & $1,3[1]$ & $1,2,3$ & $1,2,3$ & $1,2,3$ & $\begin{array}{l}2,3[1], \\
1,2[2]\end{array}$ \\
\hline Charkow & PL & 2,3 & 1 & & & & & \\
\hline Edinburgh & UK & & & & & 1,2 & & 3 \\
\hline Grenoble & F & & & & & & & \\
\hline Ischia & I & & 3 & 2,3 & $1,2,3$ & $1,2,3$ & 1,3 & $\begin{array}{c}1,3[1] \\
1,2,3[2]\end{array}$ \\
\hline Nicolaiew & RU & 2,3 & 2 & & 1,2 & & 1,2 & $2,3[1]$ \\
\hline Padua & I & & & 1,3 & & $1,2,3$ & 1 & \\
\hline Pavia & I & 3 & 3 & & & 1,3 & & \\
\hline Potsdam & D & & & & & & & \\
\hline Rocca di P. & I & $1,2,3$ & 3 & $1,3[\mathrm{I}], 3[2,3]$ & $1,2,3$ & $1,2,3$ & 1,3 & 3 \\
\hline Rome & I & $1,2,3$ & $1,2,3$ & 3 & $1,2,3$ & $1,2,3$ & $1,2,3$ & $\begin{array}{l}1,3[1] \\
1,2[2]\end{array}$ \\
\hline Shide & UK & & & & $1,2,3$ & & 1 & 3 \\
\hline Siena & I & $1,2,3$ & (1) & & & $1,2,3$ & & \\
\hline Strasbourg & $\mathrm{D}(\mathrm{F})$ & & & & 1,2 & 1 & & \\
\hline Tokyo & $\mathrm{J}$ & & 1 & & & & & \\
\hline
\end{tabular}

record in large quantities. He makes up for the modest sensitivity and the low speed of the recording $(30 \mathrm{~cm} /$ hour $)$ with his great experience in reading the traces. Due to his longstanding interest in the astronomical field he was, in addition, highly skilled in the determination of time with astronomical methods and, therefore, in the correction of the clocks of the two observatories. In this regard he had equipped the Observatory of the Grande Sentinella of Casamicciola with a meridian. As can be seen in the table, the recordings of the obser- vatories of the Island of Ischia are among those that have most recorded the earthquakes analysed by Oldham.

Figure 10 reports the concluding graph of the above-described study by Oldham, in which black dots represent the contribution of the recording of the Italian observatories, instruments of great mass and inertia.

The graph shows, as acknowledged by Oldham himself, the great contribution of the Italian instruments to this important scientific result that paved the way, with the subsequent ex- 
traordinary developments of Milne, Jeffreys, Bullen etc., to the study of the internal composition of the earth and the modelling of the gen-

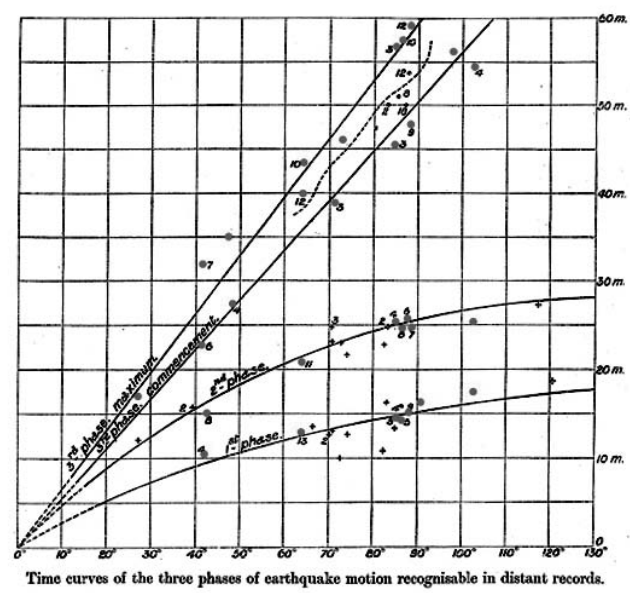

Fig. 10. Time curves of the three phases of the earthquake motion recognisable in distant records (after Oldham, 1900 modified). Black dots identify phases from Italian observatories, $74 \%$ of the total number of data used by Oldham. eration and propagation mechanisms of the earthquakes.

In 1908, the Casamicciola observatory was also equipped with a tromoseismometer, whose first recording was the Messina earthquake on 28th December 1908 (AG, Diario) the seismograms of which are still existing (fig. 11).

The care with which Grablovitz continuously made improvements to the observatory is also testified to by the intense correspondence exchanged with B. Paoloni, director of the Geodynamic and Meteorological Observatory of Montecassino, above all in regard to the intermediate corrections and the definitive correction of the respective meridian lines $\left({ }^{36}\right)$.

In 1913 he fundamentally dedicated himself to the works of the oceanographic commission for which he drafted the oceanographic programme of the Tyrennian commissioned to him by the Royal Talassographic Committee, also collaborating with the Royal Hydrographic Navy Institute.

The Avezzano earthquake on 13th January 1915 was thus noted by Grablovitz Avezzano earthquake; provenance intuited, easy to tranquillise everyone (AG, Diario).

It was the year of the War against Austria!

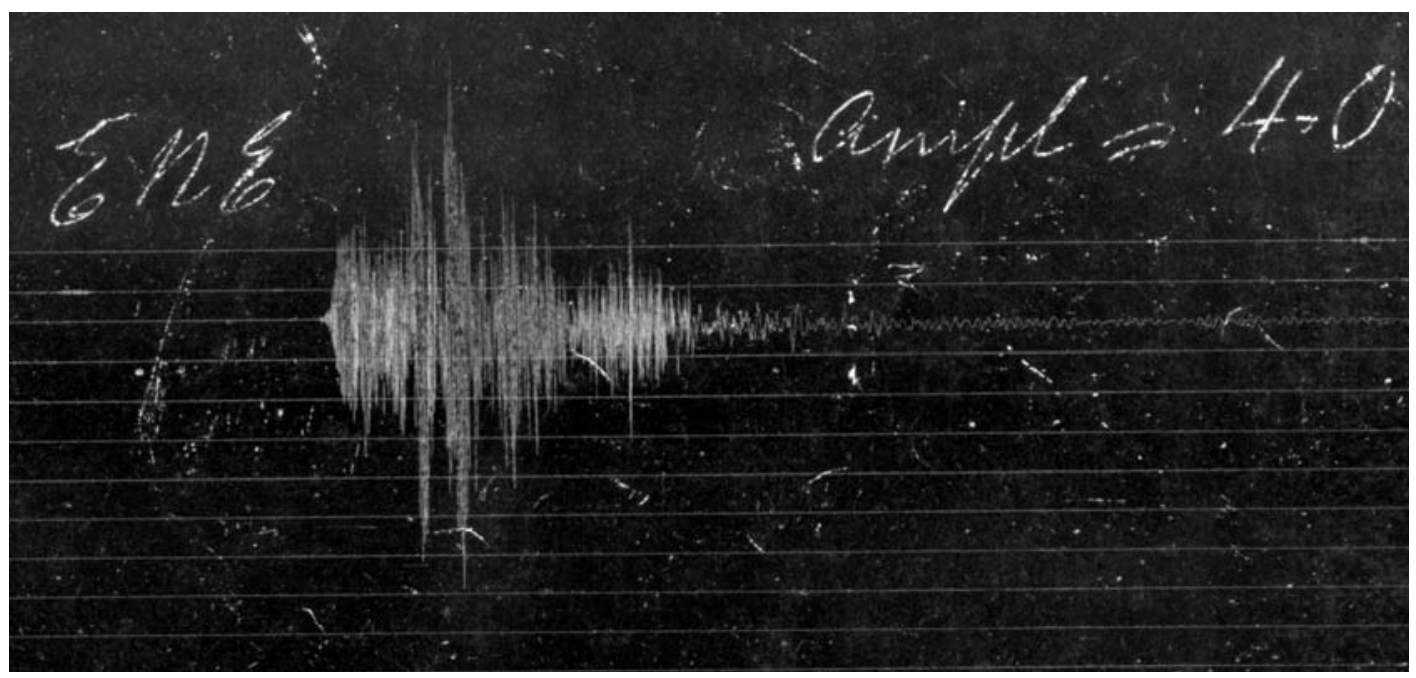

Fig. 11. Particular of the ENE-WSW component of the seismogram of the earthquake on 28th December 1908 in the Straits of Messina $(M=7.1)$, recorded at the Observatory of Porto d'Ischia by a Tromometrograph. 
and on 29th December he was appointed Cavaliere della Corona d'Italia (AG, Diario) and in 1918 the epilogue of the war and the 5 days of Trieste are thus summarised in his diary:

«The 5 days of the Liberation of Trieste October 30th The population declares the Austrian government as fallen.

October 31st Alfonso Valerio evicts the Austrian governor

November 1st Destruction of every Austrian emblem and radiotelegraphic appeal to the Italian fleet.

November 2 San Giusto anxious wait and at the vespers of the $3 \mathrm{rd}$ entrance of the Bersaglieri by sea at Trieste.

Long live redeemed.

This event closes, somewhat belatedly, but nevertheless in time, the battle-hardy stage of my life, with the crowning of my life's highest ideal.»

Before the years that followed, which continue in his diary, the words «NEW ERA stand out».

In April 1919 he took part in a meeting of the Thalassographic Committee in Pisa and during his absence the observatory lost its caretaker De Angelis (suicide by hanging).

In October 1925 Ischia hosted the Hydrological Congress and on 21st January 1926 Grablovitz was appointed «knight commander», an honour that would be officially conferred to him by the mayor of Casamicciola on 25th December while in July of the same year he again moved to Grande Sentinella.

The last entries in his diary are not his own:
1928, 5th May - Fatal fall of father. 19th September Death (AG, Diario).

\section{Conclusions}

Giulio Grablovitz was one of the most important figures in Italian and international seismology between the late 19th and the early 20th centuries, whose far-reaching and outstanding scientific production overrides the mere consultation of his rich series of publications in seismology, meteorology, oceanography.

This first study of the documentation preserved in his scientific and personal archive has been an attempt to make just a preliminary sketch of the Trieste scholar's scientific and human biographical profile, highlighting numerous aspects for future research and analysis.

The informational wealth, only briefly touch upon here, is the fruit of the extraordinary unpublished documentary wealth contained in his archive, mostly made up of a substantial epistolary collection, only partially organised.

The knowledge of other epistolary collections of seismology, analysed during the TROMOS project, has allowed us to put together part of Grablovitz's manuscripts and part of the epistolary and administrative documentation of the General Management of Agriculture and the Tacchini Archive, preserved at the CRACMA of Rome.

\section{Notes}

$\left({ }^{1}\right)$ A letter from Nicola Miraglia, General Director of the Ministry of Agriculture, Industry and Commerce to Pietro Blaserna, president of the Royal Geodynamic Commission, dated Rome, 12th September 1884 says «É superfluo poi avvertire che ove al Grablovitz venisse offerto il posto di Direttore, egli dovrebbe anzitutto rinunziare alla propria nazionalità e prendere l'italiana».

Translation: «Also, it is superfluous to warn you that should Grablovitz be offered the position as Director, he should first of all waive his own nationality and take up Italian citizenship».

Archivio Centrale dello Stato, Direzione Generale dell'Agricoltura, V versamento, busta 965, fasc. 4243, Minuta di lettera del Direttore Generale dell'Agricoltura N. Miraglia a P. Blaserna sull'impianto dell'Osservatorio Geodinamico nell'isola d'Ischia, Roma 12 settembre 1884, cc. 2;

and in another letter dated Rome, 5th November 1885: «Questo Ministero [...] promuoverà la nomina del Dr. Giulio Grablovitz a Direttore dell'Osservatorio di Casamicciola, non appena sia emanato il $R$. Decreto che accorda la naturalizzazione italiana allo stesso Dottor Grablovitz».

Translation: «This Ministry (...) will promote the appointment of Dr. Giulio Grablovitz as Director of the Observatory of Casamicciola, as soon as the Royal Decree is issued granting Dr. Grablovitz Italian naturalisation.» 
Archivio Centrale dello Stato, Direzione Generale dell'Agricoltura, V versamento, busta 962, fasc. 4230, Minuta di lettera del Ministero di Agricoltura Industria e Commercio, Direzione Generale dell'Agricoltura al Presidente della R. Commissione Geodinamica relativa all'organizzazione del servizio Geodinamico, Roma 5 novembre 1885 , cc. 7).

$\left(^{2}\right)$ Giulio Grablovitz Archive, Diary from 1846 to 1928 (hereinafter in the text AG, Diario), the archive has been temporarily entrusted to the author by the Grablovitz heirs, for purposes of study and future valorisation in an appropriate site.

$\left({ }^{3}\right)$ In 1859 with the War of Lombardy the region went under the rule of the Piedmontese.

$\left.{ }^{4}\right)$ Biblioteca dell'Ufficio Centrale di Ecologia Agraria, Fondo Tacchini, Lettera di Giulio Grablovitz a Pietro Tacchini, Trieste 3 novembre 1882.

$\left({ }^{5}\right)$ Decreto Reale di istituzione della Commissione di studio sull'ordinamento del servizio vulcanologico, Roma 20 dicembre 1883, cc. 5, Archivio Centrale dello Stato, Direzione Generale dell'Agricoltura, V versamento, busta 962 , fasc. 4230

$\left({ }^{6}\right)$ Archivio Centrale dello Stato, Direzione, Generale dell'Agricoltura, V versamento, busta 965, fasc. 4243, Lettera di G. Grablovitz a P. Tacchini di accettazione dell'incarico di esaminare il modo d'impianto dell'Osservatorio Geodinamico di Casamicciola, Trieste 15 settembre 1884, cc. 2.

$\left({ }^{7}\right)$ Archivio Centrale dello Stato, Direzione Generale dell'Agricoltura, V versamento, busta 965, fasc. 4243, Relazione di G. Grablovitz sull'impianto di un Osservatorio Geodinamico in Casamicciola, Lettera di P. Blaserna di trasmissione della medesima al Ministero di Agricoltura, Industria e Commercio, Roma 18 dicembre 1884, cc. 14; Archivio Centrale dello Stato, Direzione Generale dell'Agricoltura, V versamento, busta 965, fasc. 4243, Comunicazioni relative all'esame del progetto per l'Osservatorio Geodinamico per l'Isola d'Ischia, Roma 17-26 dicembre 1884 , cc. 3 .

$\left.{ }^{8}\right)$ Archivio Centrale dello Stato, Direzione Generale dell'Agricoltura, V versamento, busta 965, fasc. 4243, Relazione di G. Grablovitz sull'impianto di un Osservatorio Geodinamico in Casamicciola, Lettera di P. Blaserna di trasmissione della medesima al Ministero di Agricoltura, Industria e Commercio, Roma 18 dicembre 1884, cc. 14. $\left({ }^{9}\right)$ Archivio Centrale dello Stato, Direzione Generale dell'Agricoltura, V versamento, busta 962, fasc. 4230, Minuta di lettera del Ministero di Agricoltura Industria e Commercio, Direzione Generale dell'Agricoltura al Presidente della R. Commissione geodinamica relativa all'organizzazione del servizio Geodinamico, Roma 5 novembre 1885 , cc. 7.

$\left({ }^{10}\right)$ Archivio Centrale dello Stato, Direzione Generale dell'Agricoltura, V versamento, busta 965, fasc. 4243, Relazione di G. Grablovitz sull'impianto di un Osservatorio Geodinamico in Casamicciola, Lettera di P. Blaserna di trasmissione della medesima al Ministero di Agricoltura, Industria e Commercio, Roma 18 dicembre 1884, cc. 14. $\left({ }^{11}\right)$ Archivio Centrale dello Stato, Direzione Generale dell'Agricoltura, V versamento, Lettera del Segretario Generale del Ministero dei Lavori Pubblici, Segretariato Generale al Direttore Generale dell'Agricoltura del Ministero di Agricoltura Industria e Commercio, Roma 3 febbraio 1885.

$\left({ }^{12}\right)$ Archivio Centrale dello Stato Direzione Generale dell'Agricoltura, V versamento, busta 962, fasc. 4230, Minuta di lettera del Ministero di Agricoltura Industria e Commercio, Direzione Generale dell'Agricoltura al Presidente della R. Commissione geodinamica relativa all'organizzazione del servizio Geodinamico, Roma 5 novembre 1885 , cc. 7 .

$\left({ }^{13}\right)$ Archivio Centrale dello Stato Direzione Generale dell'Agricoltura, V versamento, busta 962, fasc. 4230, Decreto reale di nomina di G. Cantoni, T. Taramelli, G. Grablovitz a membri della R. Commissione Geodinamica, Monza 24 luglio 1885, cc.4.

$\left({ }^{14}\right)$ Biblioteca dell'Ufficio Centrale di Ecologia Agraria, Fondo Tacchini, Lettera di Giulio Grablovitz a Pietro Tacchini, Trieste 30 dicembre 1885.

$\left({ }^{15}\right)$ Archivio Centrale dello Stato Direzione Generale dell'Agricoltura, V versamento, busta 965, fasc. 4243, Lettera del Direttore dell'Osservatorio Geodinamico di Casamicciola alla Direzione Generale dell' Agricoltura relativa alla analisi geologica del sottosuolo della Grande Sentinella, Ischia 18 aprile 1886, cc. 2.

$\left({ }^{16}\right)$ Biblioteca dell'Ufficio Centrale di Ecologia Agraria, Fondo Tacchini, Lettera di Giulio Grablovitz a Pietro Tacchini, Napoli 1 ottobre 1887.

$\left({ }^{17}\right)$ Tacchini wrote: «[...] per impiantare un ufficio centrale geodinamico occorreva una certa somma, che il Ministero dell'Agricoltura non riusciva ad aggiungere nel proprio bilancio, così si pensò al ripiego di addossare a me la direzione di questo nuovo servizio con promesse verbali di un compenso che poi non ebbi mai. In conseguenza di questa decisione con decreto del giugno 1887 il servizio geodinamico fu unito all'Ufficio centrale di meteorologia, che perciò assunse il titolo di Ufficio Centrale di meteorologia e Geodinamica. A me toccò di provvedere alla sistemazione degli osservatori geodinamici di Catania, d'Ischia, di Rocca di Papa e di Pavia ed alla stazione sperimentale geodinamica del Collegio Romano, ed a tutto quanto riguarda il servizio che poco per volta si è andato estendendo e migliorando in tutta Italia». 
Translation: «[...] in order to install a central geodynamic office a certain sum was needed, which the Ministry of Agriculture was unable to add to its own budget, so we thought of the compromise of giving me the management of this new service with verbal promises of a fee that I later never had. As a consequence of that decision, pursuant to the decree passed in June 1887, the geodynamic service was joined to the Central Office of Meteorology, which thereby took the title of Central Office of Meteorology and Geodynamics. It was down to me to see to the setting up of the geodynamic observatories of Catania, Ischia, Rocca di Papa and Pavia and the experimental geodynamic station of Collegio Romano, and everything concerning the service that gradually grew and improved across the whole of Italy», Biblioteca Estense di Modena, Fondo Tacchini, 20A, Appunti di P. Tacchini sulla storia del Servizio Geodinamico, sl., sd., cc. 2, nn. 3-4.

$\left({ }^{18}\right)$ Archivio Centrale dello Stato, Direzione Generale dell'Agricoltura, V versamento, 963, fasc. 4239, Pratica relativa all'organizzazione dei lavori della Commissione di studio sui fenomeni vulcanici alle Eolie, Roma-Lipari 22 gennaio-16 febbraio 1889, cc. 10 .

$\left({ }^{19}\right)$ Archivio Centrale dello Stato Direzione Generale dell’Agricoltura, V versamento, 963, fasc. 4239, Pratica relativa ai problemi suscitati dalla nomina di G. Grablovitz a componente la Commissione per lo studio dei fenomeni vulcanici alle Eolie, Roma 1-4 febbraio 1889, cc. 8.

$\left({ }^{20}\right)$ Biblioteca dell'Ufficio Centrale di Ecologia Agraria, Fondo Tacchini, Lettera di Pietro Tacchini al Ministro di Agricoltura Industria e Commercio, Roma 2 febbraio 1889.

${ }^{(21)}$ Grablovitz spoke of numerous serious impediments caused by De Ferrari, who out of «personal vendetta» and by way of private manoeuvres had managed several times to remove him from his post, preventing the completion of the scientific programme: «[...] with serious prejudice to the scientific interests entrusted to me by the State and to my particular position, lies in an obstinate and unjustifiable persecution of a person employed by the Ministry for the Interior and temporarily working in Ischia. The direct aim of that individual is to disturb me in performing my duties towards the Government [...]».

${ }^{22}$ ) Biblioteca dell'Ufficio Centrale di Ecologia Agraria, Fondo Tacchini, Lettera di Pietro Tacchini a Nicola Miraglia Direttore Generale dell'Agricoltura Ministero, Roma 4 febbraio 1889.

$\left({ }^{23}\right)$ Biblioteca dell'Ufficio Centrale di Ecologia Agraria, Fondo Tacchini, Lettera di Pietro Tacchini a Nicola Miraglia Direttore Generale dell’Agricoltura, Roma 8 febbraio 1889.

$\left({ }^{24}\right)$ Archivio Centrale dello Stato, Direzione Generale dell'Agricoltura, V versamento, 966, fasc. 4248, Lettera del Direttore dell'Ufficio Centrale di Meteorologia e di Geodinamica alla Direzione Generale dell'Agricoltura sulle spese da sostenersi per l'impianto di un servizio sismico alle Isole Eolie, Roma 29 agosto 1889, cc. 4.

$\left({ }^{25}\right)$ Archivio Centrale dello Stato, Direzione Generale dell'Agricoltura, V versamento, 966, fasc. 4248, Lettera del Direttore dell'Ufficio Centrale di Meteorologia e di Geodinamica alla Direzione Generale dell' Agricoltura sulle modalità di impianto di un servizio sismico alle Eolie, Roma 8 ottobre 1889 , cc. 2.

$\left({ }^{26}\right)$ Archivio Giulio Grablovitz, Fondo G. Grablovitz, Lettera di Pietro Tacchini a Giulio Grablovitz, Casamicciola 12 luglio 1889.

$\left({ }^{27}\right) \ll[. .$.$] il Direttore di Casamicciola è il solo, dico il solo dei nostri direttori, il quale abbia indirizzo veramente$ scientifico.»e dununciando i rischi dovuti ai tagli imposti dal governo su un servizio già con poche risorse «[...] Quando agli osservatori si danno, a titolo di annua retribuzione, lire 100 o 200, una diminuzione di qualche decina di lire diventa sensibile e li disgusta. [...] in quale crudele imbarazzo doveva trovarsi il Consiglio nel respingere tutte le nuove e modeste proposte e nel restringere le modestissime condizioni già esistenti. Io non so come si andrà avanti nell'avvenire. Lo dico e lo ripeto con triste convincimento, che tutto è compromesso e che se non vi si rimedia, andrà a sfascio un servizio, che era una delle nostre glorie».

Translation: «[...] the Director of Casamicciola is the only, I repeat the only one of our directors, who has a truly scientific orientation,» and by denouncing the risks due to the cuts imposed by the government to a service that already had few resources «[...] When 100 or 200 lire are given to the observatories, as a yearly payment, a cut of a dozen or so lire becomes significant and offends them. [...] The council must find itself in cruel embarrassment in rejecting all the new and modest proposal and in restricting the very modest conditions already existing. I do not know how we can get by in the future. I say it and repeat it with sad belief, that everything is compromised and that if there is no remedy, the service will go to ruin, a service that was one of our glories.» Archivio Centrale dello Stato, Direzione Generale dell'Agricoltura, V versamento, busta 967, fasc. 4250, Lettera del Presidente del Consiglio Direttivo di Meteorologia e Geodinamica Pietro Blaserna al Ministro di Agricoltura Industria e Commercio sulle vicende del Servizio Geodinamico in Italia, Roma 1 novembre 1889, cc. 6. $\left({ }^{28}\right)$ Archivio Giulio Grablovitz, Fondo G. Grablovitz, Lettera di Giulio Grablovitz a Placido Attard, Casamicciola 23 giugno 1892 .

$\left({ }^{29}\right)$ Biblioteca Estense di Modena, Fondo Tacchini, 20M c. 342, Lettera di Giulio Grablovitz a Torquato Taramelli presidente del Consiglio Direttivo di Meteorologia e Geodinamica, sulla estensione delle ricerche mareografiche nel territorio nazionale, Ischia 17 giugno 1893, cc.1 r.v.-2 r. 
$\left({ }^{30}\right)$ Biblioteca dell'Ufficio Centrale di Ecologia Agraria, Fondo Tacchini, Lettera di Giulio Grablovitz a Pietro Tacchini, Ischia 21 marzo 1896.

$\left({ }^{31}\right)$ Archivio Giulio Grablovitz, Fondo G. Grablovitz, Copia di lettera di Giulio Grablovitz a Pietro Tacchini, 20 dicembre 1896.

$\left.{ }^{32}\right)$ «Ho costruito testé un sismografo a pendoli orizzontali con masse alquanto pesanti, in cui gli attriti e le resistenze corrispondono ad 1/30000000 (dico un trentamilionesimo) della massa e con ciò credo di poter emulare i sistemi fotografici, tanto costosi; la corsa della carta e di 30 centimetri all'ora ed a conti fatti il costo è di 30 lire [...]. Appena avrò ottenuto una bella registrazione gliene invierò la descrizione».

Translation: «I have just built a horizontal pendulum seismograph with rather heavy masses, in which the friction and the resistances correspond to $1 / 30000000$ (that is to say, one thirty millionth) of the mass and with this I believe I can emulate the photographic systems, which are so costly; the run of the paper is 30 centimetres per hour and, ultimately, the cost is 30 lire [...]. As soon I have obtained a good recording I will send you the description of it.» Biblioteca dell'Ufficio Centrale di Ecologia Agraria, Fondo Tacchini, Lettera di Giulio Grablovitz a Pietro Tacchini, Ischia 8 giugno 1896.

$\left({ }^{33}\right)$ In the earliest bulletins of the Observatory of Ebro (Tortosa) which adopted them in 1905 we can read, amongst other things, «Costruidos en 1895 por vez primera con 5 kilogramos de masa, que en los modelos actuales asciende à 12 kilogramos, los péndulos del Profesor G. Grablovitz se distinguen por su sencillez y gran baratura [...] 90 liras las dos componentes con el cilindro registrador, provisto de su mecanismo para marcar el tiempo, costruido, bajo la direcciòn del inventor, por el mecànico del Observatorio.»

Translation: «Constructed in 1895 for the first time with $5 \mathrm{~kg}$ mass, which in the current models has risen to 12 $\mathrm{kg}$, the pendulums of Professor Grablovitz are characterised by their simplicity and convenience [...] 90 lire the two components with the recording cylinder, equipped with its time-marking mechanism, built by the Observatory's mechanic, under the inventor's supervision.».

${ }^{(34)}$ «Non debbo però dissimulare l'apprensione in cui mi mette la probabilità della soppressione dell'Osservatorio del Porto [d'Ischia] ch'io per molte ragioni ritengo necessario alla compostezza dell'indirizzo intrapreso. All'epoca dell'impianto non era bene accertata l'influenza del vento e del mare ed anzi i moti sismici venivano attribuiti ad attività sismica. In oggi è provato che il colle della Grande Sentinella è grandemente soggetto a quelle influenze e gli strumenti delicatissimi che vi si trovano dimostrano questo fatto che io in base a diretta percezione dei sensi, mi rammento di aver accennato sul luogo alla S.V. Ill.ma quando era in trattativa l'espropriazione del fondo. Ciò non toglie importanza alla località che anzi è viemmaggiormente degna di studio, ma la stazione del porto è un utilissimo corollario adattatissimo alla registrazione dei terremoti lontani e dirò quasi se non esistesse sarebbe conveniente erigerla nell'interesse della scienza. Ma di quest'argomento si potrà ragionare quando la S. V. Ill.ma verrà sul posto e spero riconoscerà pure dal lato economico e l'opportunità delle mie ragioni.».

Translation: «However, I must not dissimulate the apprehension that the likelihood of the suppression of the Observatory of the Porto [d'Ischia] causes me, an observatory that for many reasons I believe necessary for the coherence of the orientation undertaken. At the time of the installation the effect of the wind and the sea was not well ascertained, and indeed the seismic motion was attributed to seismic activity. Today it is proven that the hill of the Grande Sentinella is greatly subject to those effects and the very delicate instruments that are to be found there demonstrate this fact that I, on the grounds of the direct perception of the senses, recall having mentioned in situ to your honourable self when the expropriation of the land was being negotiated. This does not reduce the importance of the location which is actually even more so worthy of study, but the station of the port is a very useful corollary highly suited to the recording of far-off earthquake and, I should say, if it did not exists, it would be convenient to erect it in the interests of science. But we may discuss this matter when you come to the site and I hope you too will recognise the economic advantages and the validity of my arguments».

Archivio Grablovitz, Fondo Giulio Grablovitz, Minuta di lettera di Giulio Grablovitz a Pietro Tacchini, Ischia 1 febbraio 1897.

$\left({ }^{35}\right)$ Letter from R.D. Oldham, from Horsham, Sussex on 18th September 1914 to Giulio Grablovitz.

«Dear Sir I have been reading with great interest your paper in the Bollettino della Società Sismologica Italiana, and regret to note that you seem to consider that I have done you an injustice in not recognizing your priority to the recognition of the three phase character of a distant seismogram. I certainly have overlooked the reference to your papers in which you had pointed out the three phases the seismogram previous to 1897, and most express my regret and apologies for having done so. In excuse I can only say that in 1897 I was still unable to read Italian, except with great difficulty and slowness; my knowledge of the language still leaves me unable to appreciate niceties of meaning, and may be that I have partially misunderstood your paper, but it seems to me that you have not fully appreciated the claim which I made in my report on the earthquake of 1897 . This was not merely that there are three recognisable phases in the seismogram, but that there was evidence of three distinct 
forms of wave motion, which differed in character and travelled in different paths and at different speeds, arriving consequently, at different times. This was the really the important new conclusion which resulted from the investigation of the earthquake of 1897, and I believe I'm right in supposing that the discovery dates from that time. I am not aware of its having been announced at an earlier date, nor could it have been established previous to 1897 when for the first time sufficiency of evidence had accumulated.

As regards the three phases of the seismogram there can be no doubt that you have fully established your claim to priority in their recognition. Yours sincerely, R.D. Oldham».

$\left({ }^{36}\right)$ Archivio Giulio Grablovitz, Fondo G. Grablovitz, Lettere di Bernardo Paoloni a Giulio Grablovitz del 1911: 29 gennaio; 4, 15 e 24 marzo; 11, 19 e 27 aprile, 11 maggio; 1 e 22 giugno; 1 luglio. Archivio Giulio Grablovitz, Fondo G. Grablovitz, Lettere di Giulio Grablovitz a Bernardo Paoloni del 1911: 8 e 13 aprile; 13 maggio; 20 giugno e 7 luglio.

\section{REFERENCES}

ABE, K. (1994): Instrumental Magnitudes of Historical Earthquakes, 1892 to 1898 , Bull. Seismol. Soc. Am., 84, 415-425.

Archivio Grablovitz, Fondo Grablovitz, Diario di Giulio Grablovitz (1846-1928) ms.

Batllò, J. (2009): Influence of G. Grablovitz in Spain: instruments and scientific correspondence, this issue.

DAvison, C. (1927): The founders of seismology, pp. 240, (London).

De Rossi, M.S. 1879-1881: La meteorologia endogena, 2 vols.

Ferrari, G., J. BAtllò and R. MACIÀ (2005): Moment Magnitude Estimation of Great Late 19th century
Earthquakes from the seismograms of Geodynamic $\mathrm{Ob}$ servatories in the Ischia Island, Poster (abstract 552), (IASPEI General Assembly, Santiago de Chile (Chile), 2-8 October 2005).

Grablovitz, G. (1913): Sulle varie fasi dei sismogrammi, Boll. della Soc. Sismol. Ital., 17, 218-244.

Milne, J. (1900): British Association for the Adv. of Science, Report 1900, 65-67.

OLDHAM, R.D. (1899): Report on the great earthquake of 12 June 1897, Memoirs of the Geological Survey of India, 29, 135-174.

OLDHAM, R.D. (1900): On the propagation of earthquake motion to great distance, Phil. Trans. Roy. Soc., A., 194, 135-174. 